\title{
Genetically monomorphic brown trout (Salmo trutta L.) populations, as revealed by mitochondrial DNA, multilocus and single- locus minisatellite (VNTR) analyses
}

\author{
PAULO A. PRODÖHL, ANDREW F. WALKER $\dagger$, ROSALEEN HYNES, JOHN B. \\ TAGGART $\$$ \& ANDREW FERGUSON* \\ School of Biology and Biochemistry, The Queen's University of Belfast, Medical Biology Centre, 97 Lisburn Road, \\ Belfast BTS 7BL, N. Ireland and †SOAEFD Freshwater Fisheries Laboratory, Pitlochry PH16 5LB, Scotland, U.K.
}

\begin{abstract}
Normally, populations of brown trout are genetically highly variable. Two adjacent populations from north-west Scotland, which had previously been found to be monomorphic for 46 proteincoding loci, were studied by higher resolution techniques. Analyses of mitochondrial DNA, multilocus DNA fingerprints and eight specific minisatellite loci revealed no genetic variation among individuals or genetic differences between the two populations. Continual low effective population sizes or severe repeated bottlenecks, as a result of low or variable recruitment, probably explain the atypical absence of genetic variation in these trout populations. Growth data do not provide any evidence of a reduction in fitness in trout from these populations.
\end{abstract}

Keywords: brown trout, inbreeding depression, minisatellite DNA, mitochondrial DNA, monomorphism.

\section{Introduction}

Loss of genetic variation arising from severe reductions in population size (bottlenecks and inbreeding) and the possible consequent reduction in fitness are major themes in conservation biology (Caughley, 1994). Based mainly on studies of captive populations, inbreeding depression is widely accepted as a fact (Keller et al., 1994). Nonetheless, the role of loss of genetic variation in the decline or extinction of natural populations is difficult to demonstrate empirically. The existence of seemingly viable populations with severely reduced or no detectable genetic variation argues against this being an inevitable outcome. Studies of variation at hypervariable DNA regions (e.g. minisatellites, the major histocompatibility complex) have revealed populations of various species, principally mammals, with reduced levels of variation compared with other populations of the same or related species (e.g. Gilbert et al., 1990; Ellegren et al., 1993; Rassmann et al., 1994). In

* Correspondence. E-mail: a.ferguson@qub.ac.uk

$\ddagger$ Present address: Department of Biological and Molecular Sciences, University of Stirling, FK9 4LA, Scotland, U.K. a widely cited example, O'Brien et al. (1985) have argued that reduced genetic variation has led to a reduction in fitness in the cheetah, Acinonyx jubatus, but this has been disputed by Caro \& Laurenson (1994) on the grounds that ecological factors, especially predation, are the chief cause of juvenile mortality. However, the two views are not necessarily mutually exclusive.

The brown trout (Salmo trutta L.), a native of Europe and south-west Asia, shows extensive variability and plasticity in its morphology, ecology and behaviour. On the basis of protein electrophoretic studies, it has been shown to have among the highest reported levels of polymorphism of any vertebrate species (Ferguson, 1989). Thus, 54 per cent of 70 loci examined in brown trout populations from throughout the native range have been found to be polymorphic, with individual populations being polymorphic at up to 35 per cent of their loci. High levels of protein polymorphism have been found in Atlantic basin brown trout populations from Denmark (Hansen et al., 1993), France (Krieg \& Guyomard, 1985), Norway (Skaala, 1992), Spain (Garcia-Marin et al., 1991; Martinez et al., 1993; 
Morán et al., 1995) and Sweden (Ryman, 1983). Partitioning of genetic diversity $\left(F_{\mathrm{ST}}\right.$; Wright, 1951) shows that, in north-west Europe, about 60 per cent of the total genetic variability is distributed among populations (Ferguson, 1989). Of more than 250 population samples that have been examined from some 60 discrete water systems in Britain, Ireland and Iceland, only the samples from two adjacent lakes in north-west Scotland were completely monomorphic at 46 protein-coding loci (Ferguson, 1989). A similar electrophoretic study of brown trout from 63 localities in Scotland (Stephen \& McAndrew, 1990 ) included one of these two populations, when it was also recorded as being uniquely monomorphic.

Studies involving mitochondrial DNA (mtDNA) (Hynes et al., 1996), multilocus minisatellite DNA patterns (DNA fingerprinting; Prodöhl et al., 1992), single-locus minisatellite profiles (Prodöhl et al., 1994) and microsatellite loci (Estoup et al., 1993) have demonstrated an even higher level of genetic variation within brown trout populations than revealed by protein studies. Taking advantage of the higher resolution of these techniques, this paper re-examines the protein-monomorphic Scottish populations on the basis of mtDNA restriction fragment length polymorphism (RFLP), minisatellite multilocus fingerprinting and single-locus profiling.

\section{Materials and methods}

In November 1990 and July 1992, samples were obtained from the brown trout populations of two small lakes (Loch na Creige Riabhaich, National Grid reference NC431505, about 12 ha; Loch Crocach, NC428490, about 25 ha). The two lakes are situated in a remote part of the Cape Wrath region of north-west Scotland at $250 \mathrm{~m}$ altitude. Although only $1 \mathrm{~km}$ apart, the lakes are separated by a 100 -m-high ridge. At the present time, there is no possibility of natural exchange of trout between the two lakes, as the outlet rivers each have a series of impassable waterfalls before they join together. Monofilament gill netting (multipanel survey nets) caught a total of 45 trout from Riabhaich and 13 trout from Crocach for DNA analyses, with growth data being available from an additional sample taken for isozyme analysis in 1982. Samples of liver and skeletal muscle tissue (approximately $1 \mathrm{~g}$ ) were preserved in 99 per cent ethanol at $4^{\circ} \mathrm{C}$ until required for DNA extraction. Genomic DNA was isolated as described by Taggart et al. (1992). Determinations of age, sex and growth characteristics were undertaken by standard methods.
For mtDNA analyses, genomic DNA extracts were digested with all six restriction enzymes previously found to reveal polymorphism in European brown trout (Hynes et al., 1996), namely AvaII, Eco RV, HaeIII, HinfI, MboI and XbaI. Gel electrophoresis and Southern blotting of the DNA fragments followed standard procedures. Blots were probed with a ${ }^{32} \mathrm{P}$-labelled purified total mtDNA probe, as described by Hynes et al. (1996).

For nuclear DNA analyses, a sample of genomic DNA ( $3 \mu \mathrm{g}$ per individual) was restriction digested with PalI (an isoschizomer of HaeIII). Gel electrophoresis, Southern blotting and probing conditions followed Taggart \& Ferguson (1990) for multilocus DNA fingerprinting, and Prodöhl et al. (1994) for single-locus DNA profiling. Multilocus fingerprint patterns were obtained using the Jeffreys' humanderived minisatellite 33.6 and 33.15 hybridization probes (Jeffreys et al., 1985). These probes had previously been shown to detect two different sets of highly variable minisatellite loci in brown trout (Taggart \& Ferguson, 1990; Prodöhl et al., 1992). Eight minisatellite loci were investigated using five single-locus probes derived from brown trout ( $\mathrm{pStr}$ A1, pStr-A3, pStr-A5, pStr-A9 and pStr-A22/2; Prodöhl et al., 1994) and three from Atlantic salmon (Salmo salar L.) (pSsa-A34, pSsa-A45/1 and pSsaA45/2; Taggart et al., 1995).

\section{Results}

Fifty-three mtDNA restriction fragments were observed, representing a total of 244 nucleotides (about 1.5 per cent of the mitochondrial genome). Only a single fragment pattern was found for each of the enzymes examined. These corresponded to pattern A for $X b a \mathrm{I}, \mathrm{B}$ for $E c o \mathrm{RV}, \mathrm{D}$ for $A v a \mathrm{II}, \mathrm{A}$ for HinfI, C for HaeIII, $\mathrm{C}$ for $\mathrm{MboI}$ and composite genotype XII as defined by Hynes et al. (1996).

Figure 1 shows typical examples of multilocus DNA fingerprints, obtained with the 33.6 multilocus probe, for brown trout from Riabhaich and Crocach and from several Irish populations. Although Scottish individuals showed multibanded patterns (i.e. $45+$ bands), all DNA fingerprints, from both within and between the two lake samples, were identical, at least in the overwhelming majority of main discernible fragments. Possible variation in some minor fragments may be artefacts, e.g. as a result of different band intensity. However, even assuming that this variation is valid, band-sharing coefficients within and between the two populations are greater than 0.95 compared with a mean of 0.33 in the 
samples from the Irish populations. A pattern $(40+$ identifiable bands) with a similar lack of variation among all individuals sampled from Riabhaich and Crocach was produced with the 33.15 probe (data not shown).

Examination of eight specific minisatellite loci (Str-A1, Str-A3, Str-A5, Str-A9, Str-A22/2, Ssa-A34, Ssa-A45/1 and $S s a-A 45 / 2$ ) showed samples from Riabhaich and Crocach to be monomorphic at all loci, with the same allele at each locus being fixed in both populations.

The ratio of female to male trout was 1:0.88 for Riabhaich and 1:1 for Crocach. The age distribution and back-calculated mean length at age for trout

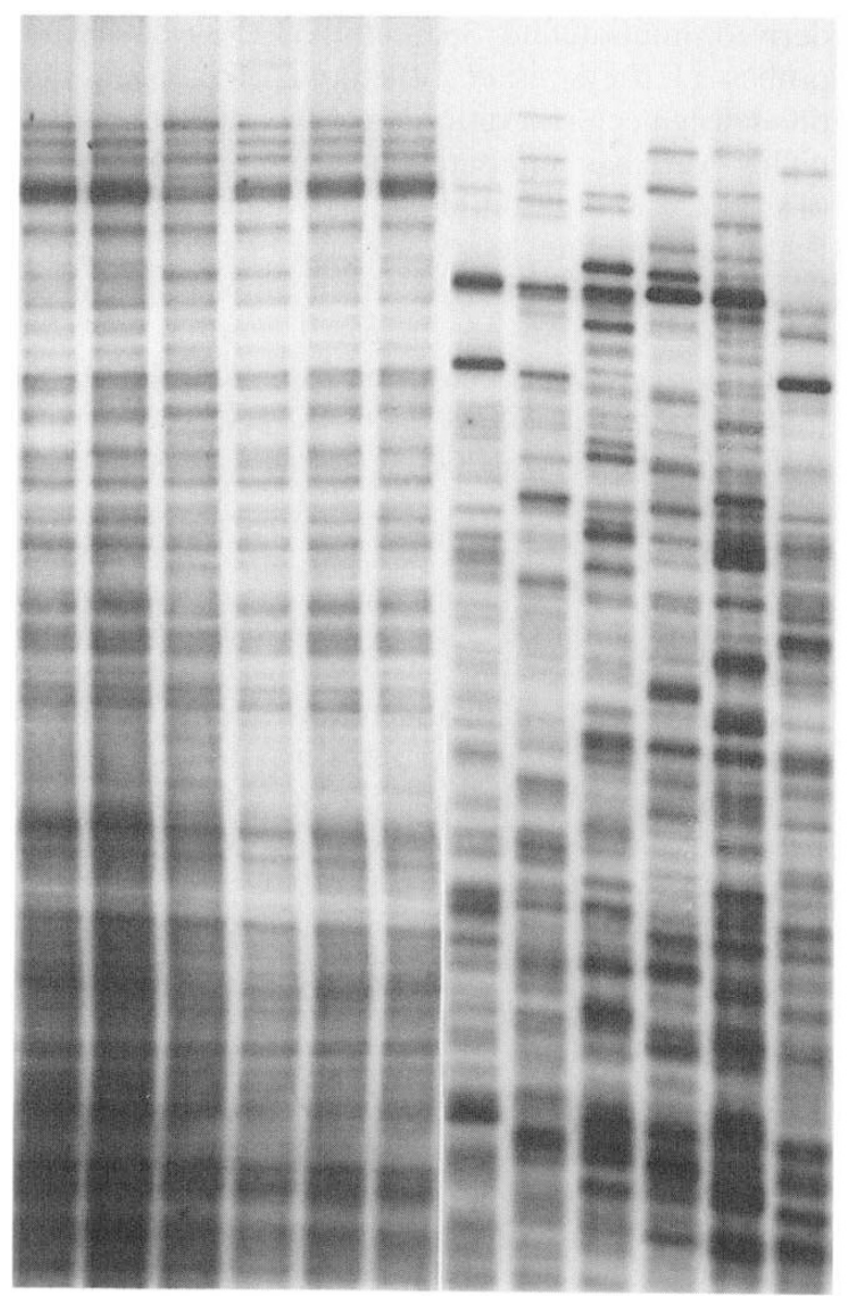

Fig. 1 DNA fingerprint patterns of brown trout produced using the Jeffreys' 33.6 human-derived probe. Fragment sizes range from approximately $2 \mathrm{~kb}$ (bottom) to $23 \mathrm{~kb}$. Samples are (from left): three from Riabhaich, three from Crocach, two individuals each from a fish farm and two wild populations in Ireland.
Table I Age and length data for 57 brown trout from Riabhaich and 19 from Crocach

\begin{tabular}{|c|c|c|c|c|}
\hline \multirow[b]{2}{*}{ Age } & \multicolumn{2}{|c|}{ Riabhaich } & \multicolumn{2}{|c|}{ Crocach } \\
\hline & Number & Length (SD) & Number & Length (SD) \\
\hline 1 & 2 & $123(7)$ & 0 & \\
\hline 2 & 28 & $195(39)$ & 1 & 172 \\
\hline 3 & 8 & $240(39)$ & 1 & 262 \\
\hline 4 & 7 & $270(41)$ & 9 & $287(24)$ \\
\hline 5 & 9 & $308(25)$ & 3 & $374(15)$ \\
\hline 6 & 3 & $363(10)$ & 2 & $440(43)$ \\
\hline 7 & 0 & & 3 & $485(39)$ \\
\hline
\end{tabular}

Age was determined from scales and refers to winters. Mean fork length is in $\mathrm{mm}$ and refers to back-calculated length at the end of the growing season. Standard deviation is given in brackets.

from these lakes are shown in Table 1. Both mature males (fourth year and older) and females (fifth year and older) were present in the samples.

\section{Discussion}

The mtDNA, single-locus and multilocus minisatellite studies reveal no or, at best in the case of the multilocus patterns, extremely low variation in the samples of brown trout from Riabhaich and Crocach. This situation is in marked contrast to what has been found in other brown trout populations in north-west Europe.

In 37 samples from other populations in northwest Europe examined by Hynes et al. (1996), using the same restriction enzymes as in this study, three Irish populations and 13 Icelandic populations of brown trout showed no mtDNA variation. As a result of its maternal inheritance and haploid nature, mtDNA has one-quarter the effective population size relative to nuclear genes and, consequently, mtDNA variation is more easily lost during population bottlenecks. Thus, lack of variability in mtDNA may be less surprising than for the nuclear minisatellite genes. The haplotype found in samples from Riabhaich and Crocach was also found in trout populations from Ireland and Poland (Hynes et al., 1996).

The monomorphism, or near-monomorphism, in multilocus DNA fingerprints is particularly unexpected. Pedigree analysis of brown trout DNA fingerprints resolved with the 33.6 and 33.15 probes have shown that most bands represent different loci (Taggart \& Ferguson, 1990). Prodöhl et al. (1992)

(C) The Genetical Society of Great Britain, Heredity, 79, 208-213. 
found highly variable fingerprints among brown trout individuals from each of the three sympatric populations in Lough Melvin (Ireland), including the ferox type, which was found to be monomorphic for mtDNA (Hynes et al., 1996).

More convincing evidence of lack of variation is given by the single-locus minisatellite analyses, as these are not subject to the technical and interpretation limitations of multilocus fingerprints. All other brown trout populations screened to date (Ferguson et al., 1995), using the same locus-specific minisatellite probes as in this study, showed extensive polymorphism even when similar sample sizes to those examined from Riabhaich and Crocach are considered. These include all 16 populations that were monomorphic for mtDNA (see above). Mean heterozygosity values ranged from 0.22 to 0.69 , and the mean number of alleles per locus per population from 2.3 to 7.7 (Ferguson et al., 1995). Highest levels of variability occurred in anadromous trout populations in Scotland and Ireland, with up to 14 alleles at a locus in a population (Thompson, 1995). Typically also, geographically separate brown trout populations are genetically distinct (Ferguson et al., 1995).

The trout populations in Riabhaich and Crocach are thus unique among studied brown trout populations from Iceland, Ireland and Scotland in that they do not show genetic variation, within or between populations, with any of the molecular techniques employed to date. This raises several questions. How has this atypical monomorphism arisen? Why are the populations in the two adjacent but unconnected lakes fixed for the same alleles at all loci? What are the fitness implications of this lack of variation? Fisheries records available for the area register the occurrence of brown trout in Riabhaich and Crocach for over 100 years, although whether they result from natural or artificial introduction before this time is not known. Although the lakes could not be colonized naturally today, in earlier postglacial times before isostatic uplift and waterfall erosion, such colonization would probably have been possible. Because of a distinctive coloration of trout in the two lakes, care has been taken by the estate owners to prevent stocking of these lakes. It may be, however, that interlake transplants have occurred without being recorded, and this is the most likely explanation for the genetically identical populations in the two lakes. However, even if the populations were artificially founded using individuals from even a single family from any other known population of brown trout in western Europe, variability would still be expected, given the level of heterozygosity in these populations. Thus, irrespective of whether colonization was natural or artificial, the extreme level of monomorphism, particularly involving usually highly variable minisatellite loci, requires explanation.

Most lake-dwelling brown trout in Britain and Ireland are river spawners. In the case of Riabhaich and Crocach, the outlet rivers fall almost immediately over steep cliffs and thus could not serve as nursery areas. Each lake has a single small inlet stream. Electrofishing on two occasions in these streams failed to find juvenile fish. One- and two-year-old trout were present in the lake samples, whereas these age groups would normally be expected to be still in the rivers. It would appear that either juveniles migrate downstream very early or the trout atypically spawn on the beds of the lakes. These comprise mainly rounded rubble and suitable spawning and nursery conditions may be limited. In either case, recruitment is likely to be low and temporally variable. Continual low effective population sizes or repeated severe bottlenecks could result in monomorphism in relatively few generations compared with the time that these populations have potentially been in existence.

Of the other European populations of brown trout examined by the authors (Prodöhl, 1993), the next lowest level of variation found (as judged by combined protein, mtDNA and minisatellite analyses) was in the lakes of the Veidivötn system, adjacent to the Vatnajökull glacier in central Iceland. These lakes form a row of water-filled explosion craters surrounded by volcanic ash, and in most cases there are no inlet or outlet rivers. Thus, the trout here are obligate lake spawners and, because spawning conditions are poor and the lakes are frozen over throughout the winter, the recruitment is low and variable (Kristjánsson, 1978).

A common consequence of the reduction of genetic variability is an increase in population vulnerability and reduction in individual fitness. This is because homozygosity exposes deleterious recessive alleles, negates individual locus heterosis and limits the possibility for future adaptation. Genetic theory predicts that this will be manifested in lower fecundity, higher infant mortality and reduced growth rates (Caro \& Laurenson, 1994). In fish, growth rate is a good predictor of fitness, as survival, time of maturation and fecundity are size-related. Campbell (1971) ranked the growth rate of brown trout in 24 lakes in northern Scotland on the basis of the size at the fourth winter. By comparison, backcalculated lengths of trout from Riabhaich and Crocach would be equivalent to the 12 th and 10 th rank of his populations. That is, the growth rates are 
'average' among northern Scottish populations. More detailed information on fecundity, juvenile survival and disease resistance of these trout is required before definitive conclusions on fitness can be drawn. However, one could speculate that the multiple bottlenecks and subsequent inbreeding may have been sufficient to purge deleterious alleles from the populations with a subsequent recovery of fitness (Brakefield \& Sacchini, 1994).

These populations represent a unique opportunity to investigate the relationship between lack of genetic variation in natural populations and fitness. These highly homozygous trout provide the equivalent of highly inbred strains of laboratory mice or rats and would be extremely valuable in experimental situations for the purpose of disentangling the effects of genotype and environment, and for gene mapping and linkage studies. Given the scientific importance of these populations, it is essential that both in situ and ex situ conservation measures are taken. Such genetically unique populations would be highly vulnerable even to a small amount of stocking with non-native trout (Hansen \& Loeschcke, 1994).

\section{Acknowledgements}

We are grateful to the estate owner for permitting sampling of the lakes, and to S. J. Dora, I. McDonald and A. M. Walker for assistance with fishing. We also gratefully acknowledge R. Niall Campbell for drawing our attention to these morphologically distinct trout populations, and J. C. Avise for helpful comments on the manuscript. P.A.P. was supported by studentship no. 487/89-5 from CAPES (Brazil) and J.B.T. by a NERC advanced fellowship.

\section{References}

BRAKEFIELD, P. M. AND SACChIN1, I. J. 1994. Guidelines in conservation genetics and the use of the population cage experiments with butterflies to investigate the effects of genetic drift and inbreeding. In: Loeschcke, V., Tomiuk, J. and Jain, S. K. (eds) Conservation Genetics, pp. 165-179. Birkhäuser Verlag, Basle.

CAMPBELL, R. N. 1971. The growth of brown trout Salmo trutta L. in northern Scottish lochs with special reference to the improvement of fisheries. J. Fish Biol., 3, $1-28$.

CARO, T. M. AND LAURENSON, M. K. 1994. Ecological and genetic factors in conservation: a cautionary tale. Science, 263, 485-486.
CAughley, G. 1994. Directions in conservation biology. $J$. Anim. Ecol., 63, 215-244.

ELLEGREN, H., HARTMAN, G., JOHANSSON, M. AND ANDERSSON, L. 1993. Major histocompatibility complex monomorphism and low levels of DNA fingerprinting variability in a reintroduced and rapidly expanding population of beavers. Proc. Natl. Acad. Sci. U.S.A., 90, $8150-8153$.

ESTOUP, A., PRESA, P., KRIEG, F., VAIMAN, D. AND GUYOMARD, R. 1993. (CT) $)_{n}$ and $(\mathrm{GT})_{n}$ microsatellites: a new class of genetic markers for Salmo trutta L. (brown trout). Heredity, 71, 488-496.

FERGUSON, A. 1989. Genetic differences among brown trout, Salmo trutta, stocks and their importance for the conservation and management of the species. Freshw. Biol., 21, 35-46.

FERGuson, A., TAGgART, J. B., PRODÖHL, P. A., McMeEl, O., THOMPSON, C., STONE, C. ET AL. 1995. The application of molecular markers to the study and conservation of fish populations, with special reference to Salmo. J. Fish Biol., 47 (suppl.), 103-126.

GARCIA-MARIN, J. L., JORDE, P. E., RYMAN, N., UTTER, F. AND PLA, C. 1991. Management implications of genetic differentiation between native and hatchery populations of brown trout (Salmo trutta) in Spain. Aquaculture, 95, $235-249$

GILBERT, D. A., LEHMAN, N., O'BRIEN, S. J. AND WAYNE, R, K. 1990. Genetic fingerprinting reflects population differentiation in the California Channel Island fox. Nature, 344, 764-767.

HANSEN, M. M. AND LOESCHCKE, V. 1994. Effects of releasing hatchery-reared brown trout to wild trout populations. In: Loeschcke, V., Tomiuk, J. and Jain, S. K. (eds) Conservation Genetics, pp. 273-289. Birkhäuser Verlag, Basle.

HANSEN, M. M., LOESCHCKE, V., RASMUSSEN, G. AND SIMONSEN, V. 1993. Genetic differentiation among Danish brown trout (Salmo trutta) populations. Hereditas, 118 , $177-185$

HYNES, R. A., FERGUSON, A. AND MCCANN, M. A. 1996. Variation in mitochondrial DNA and post-glacial colonisation of north western Europe by brown trout. J. Fish Biol., 48, 54-67.

JEFFREYS, A. J., WILSON, V. AND THEIN, S. L. 1985. Individual-specific 'fingerprints' of human DNA. Nature, 316, 76-79.

KELLER, L. F., ARCESE, P., SMITH, J. N. M., HOCHACHKA, W. M. AND STEARNS, S. C. 1994. Selection against inbred song sparrows during a natural population bottleneck. Nature, 372, 356-357.

KRIEG, F. AND GUYOMARD, R. 1985. Population genetics of French brown trout (Salmo trutta L): large geographical differentiation of wild populations and high similarity of domesticated stocks. Génét. Sél. Évol, 17, 225-242.

KRISTJÁNSSON, J. 1978. Growth rates of brown trout and Arctic char in Iceland. J. Agric. Res. Icel., 10, 125-134.

MARTINEZ, P., ARIAS, J., CASTRO, J. AND SANCHEZ, L. 1993. Differential stocking incidence in brown trout (Salmo 
trutta) populations from Northwestern Spain. Aquaculture, 114, 203-216.

MORÁN, P., PENDÁS, A. M., GARCÍA-VÁZQUEZ, E., IZQUIERDO, J. I. AND LOBÓN-CERVIÁ, J. 1995. Estimates of gene flow among neighbouring populations of brown trout. J. Fish Biol., 46, 593-602.

o'Brien, s. J., ROELKE, M. E., MARKER, L., NEWMAN, A., WINKLER, C. A., MELTZER, D. ET AL. 1985. Genetic basis for species vulnerability in the cheetah. Science, 227, 1428-1434.

PRODÖHL, P. A. 1993. Multilocus and Single Locus Minisatellite DNA Polymorphism in Brown Trout (Salmo trutta L.) Populations. Ph.D. Thesis, The Queen's University of Belfast.

PRODÖHL, P. A., TAGGART, J. B. AND FERGUSON, A. 1992. Genetic variability within and among sympatric brown trout (Salmo trutta) populations: multi-locus DNA fingerprint analysis. Hereditas, 117, 45-50.

PRODÖHL, P. A., TAGGART, J. B. AND FERGUSON, A. 1994. Single locus inheritance and joint segregation analysis of minisatellite (VNTR) DNA loci in brown trout (Salmo trutta L.). Heredity, 73, 556-566.

RASSMANN, K., ARNOLD, w. AND TAUTZ, D. 1994. Low genetic variability in a natural alpine marmot population (Marmota marmota, Sciuridae) revealed by DNA fingerprinting. Mol. Ecol., 3, 347-353.
RYMAN, N. 1983. Patterns of distribution of biochemical genetic variation in salmonids: differences between species. Aquaculture, 33, 1-21.

SKAALA, $\varnothing$. 1992. Genetic population structure of Norwegian brown trout. J. Fish Biol., 41, 631-646.

STEPHEN, A. B. AND McANDREW, B. J. 1990. Distribution of genetic variation in brown trout, Salmo trutta, L., in Scotland. Aquacult. Fish. Manage., 21, 47-66.

TAGgART, J. B. AND FERGUSON, A. 1990. Minisatellite DNA fingerprints of salmonid fishes. Anim. Genet., 21, 377-389.

TAGgaRT, J. B., HYNES, R. A., PRODÖHL, P. A. AND FERGUSON, A. 1992. A simplified protocol for routine total DNA isolation from salmonid fishes. J. Fish Biol., 40, 963-965.

TAGgart, J. B., PRODÖHL, P. A. AND FERGUSON, A. 1995. Genetic markers for Atlantic salmon (Salmo salar L.). Single locus inheritance and joint segregation analyses of minisatellite (VNTR) DNA loci. Anim. Genet., 26, $13-20$.

THOMpSOn, C. E. M. 1995. Population Genetics of Anadromous Brown Trout (Salmo trutta L.) in Scotland and Ireland. Ph.D. Thesis, The Queen's University of Belfast.

WRIGHT, s. 1951. The genetical structure of populations. Ann. Eugen., 15, 323-354. 